\title{
Formulation and Validation of Model for Calculating the Number of Probe Cars Considering Traffic Information Update Frequency
}

\author{
Takumi Fushiki Non-member (Hitachi, Ltd., tfushiki@gm.hrl.hitachi.co.jp) \\ Takayoshi Yokota Member (Hitachi,Ltd., tyokota@gm.hrl.hitachi.co.jp) \\ Kazuya KimitaＮon-member（Hitachi, Ltd., kkimita@gm.hrl.hitachi.co.jp) \\ Masatoshi Kumagai Non-member (Hitachi, Ltd., mkumagai@gm.hrl.hitachi.co.jp)
}

Keywords: ITS, telematics, traffic information service, probe car, update frequency, probabilistic model

Probe cars are very effective tools in traffic information gathering. We formulate the probabilistic relationships among the traffic volume of probe cars, the area coverage, and the update frequency of traffic information provision. We also validate the theoretical formulation with experimental probe car data collected in a taxi monitoring system.

In order to formulate the relation between the area coverage and the update frequency of traffic information under the condition of a certain density of probe cars, we assume the condition as follows:

1. Traffic flow: uniform and constant density and velocity on an infinite straight road.

2. The information from a probe car is absolutely reliable, if passing on a road section at only one time.

Fig. 1 shows an example of arrangement of probe cars on a road. $v[\mathrm{~m} / \mathrm{s}]$ means the velocity of probe cars, $t[\mathrm{~s}]$ means the update frequency of traffic information and $N$ means the number of probe cars. We assume the realistic case that the running area of probe cars overlap with each other as shown in Fig. 1. The running area of one probe car after the time when it reaches to the running area of another probe car is redundant for gathering traffic information under the above-mentioned 2nd assumption. We, therefore, consider the reduction of the area coverage rate caused by the overlap. Assuming that the distribution of the headway of probe cars is expressed as exponential distribution, the area coverage rate $\beta$ in the update frequency $t[\mathrm{~s}]$ is inducted by using traffic volume of probe cars $Q^{\prime}$ [veh/s] as follows using Eq. (1).

$$
\beta=\left(1-\exp \left(-Q^{\prime} t\right)\right)^{2}+Q^{\prime} t \exp \left(-2 Q^{\prime} t\right)
$$

\section{Probe car Non-probe car $\bigcirc$}

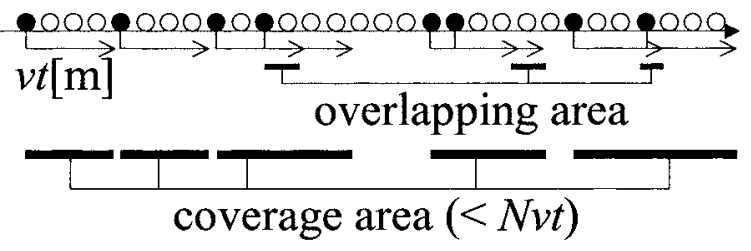

Fig. 1. Arrangement of probe cars
We validate the theoretical formulation in Eq. (1) comparing the experimental area coverage rate with the theoretical area coverage rate using experimental probe car data collected in a taxi monitoring system. We utilized GPS time and location data in cooperation with a taxi corporation located in Hitachi-City, which has a population of about 200,000. We got probe car data from 38 taxis and examined the data from $07 / 01 / 2001$ to $07 / 31 / 2001$. We calculated the mean values of the probe volume and the area coverage rate with update frequencies of 5, 10, 30 and 60 minutes for the month. Then we estimated the theoretical area coverage rate using Eq. (1) from the experimental probe volume input. Fig. 2 shows the result of the comparison between the experimental and theoretical values for the area coverage rate at 10 minutes update frequency. Table 1 shows the average error rate between the experimental and the theoretical area coverage rate of each update frequency. There is a good correlation between the experimental result and the theoretical estimate in Fig. 2 and Table 1, which confirms the validity of the theoretical formulation.

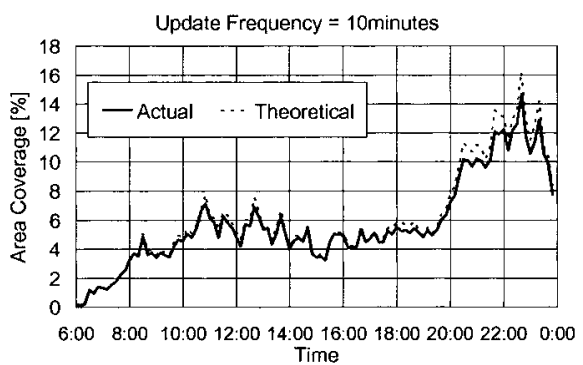

Fig. 2. Actual and theoretical area coverage at $10 \mathrm{~min}-$ utes update frequency

Table 1. Error of area coverage

\begin{tabular}{|c|c|}
\hline Update Frequency & Error Rate \\
\hline $5 \mathrm{~min}$. & $3.8 \%$ \\
\hline $10 \mathrm{~min}$. & $5.8 \%$ \\
\hline $30 \mathrm{~min}$. & $11.5 \%$ \\
\hline $60 \mathrm{~min}$. & $17.9 \%$ \\
\hline
\end{tabular}




\title{
交通情報提供の更新周期を考慮した プローブカー台数算出モデルの定式化とその評価
}

\author{
非会員 伏木 匠* 正 員 横田 孝義* \\ 非会員 君田 和也* 非会員 熊谷 正俊* \\ Formulation and Validation of Model for Calculating the Number of Probe Cars \\ Considering Traffic Information Update Frequency \\ Takumi Fushiki*, Non-member, Takayoshi Yokota*, Member, \\ Kazuya Kimita*, Non-member, Masatoshi Kumagai*, Non-member
}

\begin{abstract}
Probe cars are very effective tools in traffic information gathering. Probe cars can collect the traffic condition data without using roadside sensors but with only using their own equipped sensors. By using probe cars, it is expected that the accuracy of traffic information will be improved and the area coverage of the traffic information service will be increased, and many experimental probe car data collection projects have been implemented. However, the number of probe cars required for adequate information update frequency has not been theoretically discussed. This paper formulates the probabilistic relationships among the traffic volume of probe cars, the area coverage, and the update frequency of traffic information provision. This formulation calculates the adequate number of probe cars to realize traffic information services in advance considering two major service factors: area coverage and update frequency. This paper also validates the theoretical formulation with experimental probe car data collected in a taxi monitoring system.
\end{abstract}

キーワード : ITS, テレマティクス, 交通情報提供, プローブカー, 更新周期, 確率モデル

Keywords: ITS, telematics, traffic information service, probe car, update frequency, probabilistic model

\section{1. まえがき}

ITS（Intelligent Transport Systems：高度道路交通システ ム）は，安全，利便，かつ快適な社会を実現するキー技術 となってきた。この 10 年間，我々は，センサ技術，車両安 全システム, カーナビゲーションシステム, DSRC, ETC などを通じて，ITS に対して大きな貢献をしてきた。交通 情報サービスもまた, 我々のITS アプリケーションとして 重要な位置付けにある。現在, 交通情報サービスは, 従来 の公共的なサービスからテレマティクスサービスの一重要 サービスとして変化しつつある ${ }^{(1) \sim(3)}$ 。

プローブカーを用いた交通情報サービスは，新しいテレ マティクスサービスとして注目されている。プローブカー を用いた交通情報システムを図 1 に示す。眓 1 に示すよう に，プローブカーは，車両自身が交通情報収集のセンサと して振る舞い, 自身の位置, 時刻情報を収集する。収集さ

\footnotetext{
* 日立製作所日立研究所

干 319-1292 日立市大みか町 7-1-1

Hitachi Research Lab., Hitachi, Ltd.

7-1-1, Omika-cho, Hitachi 319-1292
}

れた情報（＝プローブ情報）はセンタにアップリンクされ， センタではプローブ情報を加工して交通情報に変換する。 作成した交通情報はカーナビゲーション，インターネット， 携帯電話等各種媒体向けに提供され, 活用される。プロー ブカーによる交通情報収集は, 交通情報の精度向上, 情報 収集カバーエリアの拡大に役立つと期待されている。

プローブカーを実際の交通情報収集システムとして利用 するためには，事前に情報収集に必要な混入率，台数を見 積もる必要がある。過去にプローブカーを交通情報源とし て利用し, 必要な混入率を試算した研究事例としては, プ ローブカー台数と混入率から交通情報提供のサービスエリ アを試算したもの ${ }^{(4)}$, 混入率と情報精度との関係をシミュ レートしたもの (5) などが挙げられる。これらの研究事例に よれば, 統計的な交通情報収集に $1 \%$ 程度, リアルタイム の交通情報収集には $5 \%$ 程度のプローブカー混入率が必要 である，としている。また，トリップ原単位の指標を導入 し, リンクのカバー率を試算し, 実際のプローブ情報を用 いて評価した研究事例 ${ }^{(6)} も$ あ。

前述した研究事例では, プローブカーの走行カバー率 (本 論文ではエリアカバー率として統一), 及び走行頻度に関す 


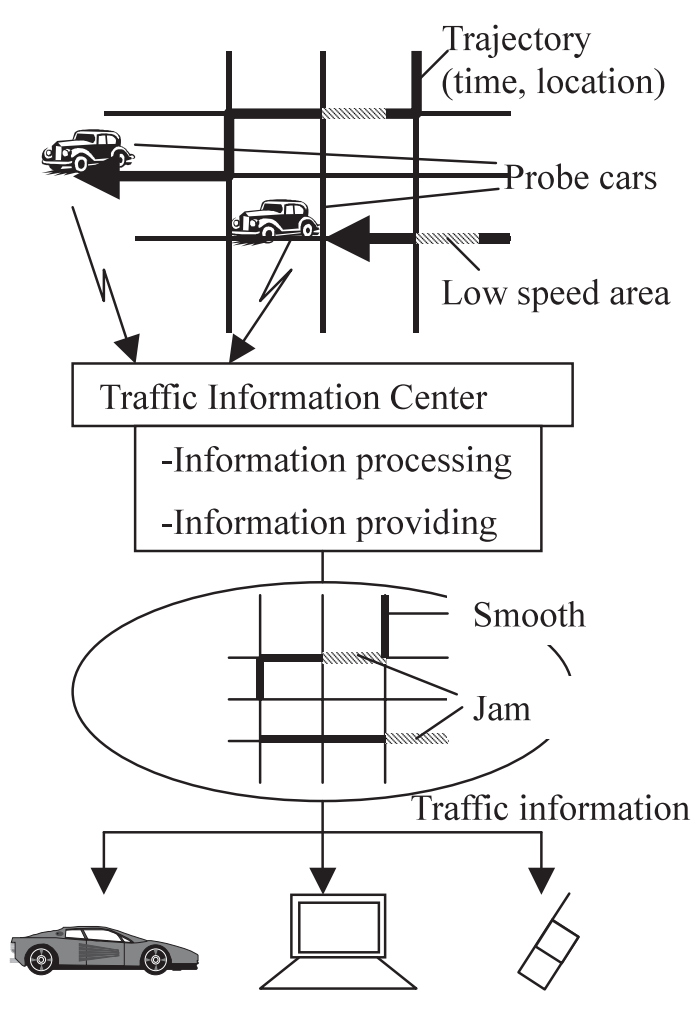

Car Navigation Internet Cell phone

図 1 プローブカーを用いた交通情報システム

Fig. 1. Traffic information system using probe cars.

る検討はなされている。ただし，プローブカーの走行エリ アの重複を考慮すると，プローブカーの走行頻度と提供す る交通情報の更新頻度は必ずしも一致せず，その関係を考 慮する必要がある。本論文では，プローブカーの走行頻度 と交通情報更新周期との関係に注目し，プローブ情報を交 通情報として活用する際の必要プローブカー交通量を指標 として，エリアカバー率と交通情報更新周期との関係を，プ ローブカーの出現確率を考慮したモデルを用いて定式化し た。また，具体的数值を用いて交通情報提供サービスに必 要なプローブカー走行台数を試算した。さらに実際のタク シーAVM（Automatic Vehicle Monitoring）システムの位 置情報データをプローブカーデータとして利用し，実際の エリアカバー率を求めて, 本論文によって導出した理論式 の有効性を評価した。

\section{2. プローブカーによる交通情報提供のためのエリ アカバー率算出式の定式化}

本章では，エリアカバー率と交通情報更新周期との関係 を定式化の方法について説明する。本論文で目的とする定 式化は，プローブカーによる交通情報提供システムを構築 するための事前計画時に利用することを想定している。事 前計画段階では, システム導入区間の交通量, 走行速度, 道 路距離延長などの代表的な交通パラメータから簡便に必要 プローブカー台数が算出できることが望まれる。地点通過

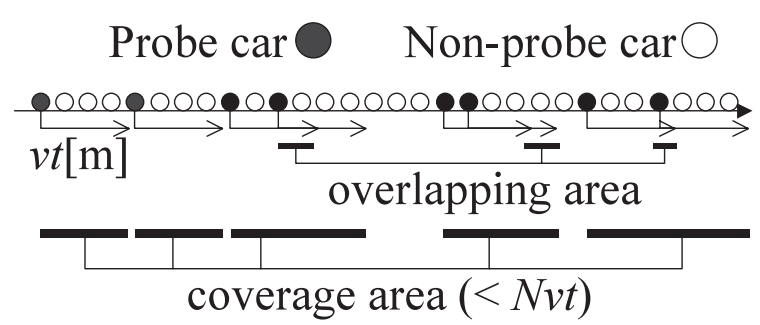

図 2 プローブカーの道路上での配置

Fig. 2. Arrangement of probe cars.

交通量データ，交通流モデル等を用いてシミュレーション により計算することで高精度に必要台数を推定することも 可能であるが，シミュレーション自体に時間，工数を要し， システムの導入自体が遅延する危険性がある。よって，本 論文のモデル化では，実際の交通状態，プローブカーの配 置等を現実的かつ簡便な確率モデルで表現し，簡単なパラ メータで表現可能となるような定式化を目指した。

モデル化のために，以下の条件を仮定する。

1. 対象区間は, 一次元無限長の直線道路とする。

2. 対象区間内部では，一様，一定の交通流を仮定し，交 通量，密度，速度は一定であるとする。

3. プローブ情報は，一台から得られたものであっても絶 対的に信頼できるものと仮定し，一度でもプローブカー が通過した領域は，情報収集が完了したエリアとする。

図 2 はプローブカーの道路上での配置状況を表し, $v[\mathrm{~m} / \mathrm{s}]$ はプローブカーの平均移動速度, $t[\mathrm{~s}]$ は情報更新周期, あ る区間内に存在するプローブカーの台数を $\mathrm{N}$ [台] とする。 その他の各パラメータは以下に示す。

$k[$ 台 $/ \mathrm{m}]:$ 車両密度

$\gamma:$ プローブカー混入率

$Q$ : 交通流率 [台/s] 一定密度, 速度下では $Q=k v$ の関係 式が成立

$Q^{\prime}=\gamma Q[$ 台 $/ \mathrm{s}]:$ プローブカーの交通量を表し，プローブ カー交通量と定義

図 2 では，プローブカーが等間隔で存在せず，不均一に 配置される，現実的な交通状況を想定している。前方との 車頭間隔距離が平均車頭間隔よりも小さい場合には，情報 更新周期 $t$ [s] を経過する以前に，前方プローブカーが走 行した区間との重なりが発生する。前記第 3 の仮定から, プローブカーが一台でも走行した箇所の情報は，同一情報 更新周期内では同一の情報とみなされる。このため，重な りが発生した時刻以降ではプローブカーが走行することに よって新たな情報収集をしたことにならず，重なりの分工 リアカバー率が低減することを考慮する必要がある。密度 $(=k[$ 台 $/ \mathrm{m}])$ の交通流において，プローブカー混入率 $\gamma[1 /$ 台]におけるプローブカーの車頭距離間隔 $x 0[\mathrm{~m}]$ の確率密 度分布 $f(x 0)[1 / \mathrm{m}]$ は，一般に期待值 $1 / k \gamma[\mathrm{m}]$ の指数分布 と仮定でき，(1)式で表せる(7)

$$
f(x 0)=P(X=x 0)=k \gamma \exp (-k \gamma x 0)
$$


また，プローブカーの車頭時間間隔 $t 0=x 0 / v[\mathrm{~s}]$ も同様に 期待值 $1 / k \gamma v[\mathrm{~s}]$ の指数分布となり, 確率密度分布 $g(t 0)[1 / \mathrm{s}]$ は，(2) 式，累積分布関数 $G(t 0)$ は以下の (3) 式で表せる。

$$
\begin{aligned}
& g(t 0)=P(T=t 0)=k \gamma v \exp (-k \gamma v t 0) \\
& G(t 0)=P(T \leq t 0)=1-\exp (-k \gamma v t 0)
\end{aligned}
$$

一方, 情報収集周期 $t[\mathrm{~s}]$ を経過後に, $\mathrm{N}$ 台の車両のうち $\mathrm{M}$ 台 が前車の走行軌跡と重なったとする。 $\mathrm{M}$ 台分のカバー距離 合計を $D_{\text {overlap }}$, 前車との走行軌跡が重ならなかった $(\mathrm{N}-\mathrm{M})$ 台分のカバー距離合計を $D_{\text {non_overlap }}$, 及びエリアカバー率 対象区間の距離を $D_{\text {section }}$ とすると, エリアカバー率 $\beta$ は以 下の (4) 式で表すことができる。

$$
\beta=\frac{D_{\text {overlap }}+D_{\text {non_overlap }}}{D_{\text {section }}}=\frac{D_{\text {overlap }}+(N-M) v t}{N / k \gamma}
$$

(4) 式において, $D_{\text {section }}$ は N 台の車両が期待值 $1 / k \gamma[\mathrm{m}]$ の 車頭距離間隔で存在する区間合計距離として表すことがで きる。また， D non_overlap は車両間の走行軌跡の重なりが存 在しない車両のカバー距離であるので, 1 台当たりのカバー 距離=走行距離となり, 走行距離期待值 $v t[\mathrm{~m}]$ に台数を乗 ずることで算出できる。走行軌跡が重なった車両の台数 M は全体 $\mathrm{N}$ 台に対して車頭時間間隔＜情報更新周期となった 車両とみなすことができるので，(3) 式を用いて以下の (5) 式で表すことができる。

$$
M=N(1-\exp (-k \gamma v t))=N\left(1-\exp \left(-Q^{\prime} t\right)\right) \cdots
$$

$D_{\text {overlap }}$ は，車両間走行軌跡の重なりのためにカバー距離 =車頭距離となることに注目して算出する。D $D_{\text {overlap }}$ は，プ ローブカーの車頭距離間隔 <情報更新周期内の走行距離で ある $\mathrm{M}$ 台の車両の走行距離合計であるので，(1) 式を用い て以下の (6) 式で表すことができる。

$$
D_{\text {overlap }}=M \int_{0}^{v t} x f(x) d x=M \int_{0}^{v t} x \cdot k \gamma \exp (-k \gamma x) d x
$$

(4) 式に(5)，(6) 式を代入し, さらに, $Q=k v, Q^{\prime}=\gamma Q$ の 関係式を利用してプローブカー交通量で表すと，情報更新 周期 $t[\mathrm{~s}]$ 経過後のエリアカバー率 $\beta$ は以下の (7) 式で表す ことができる。

$$
\beta=\left(1-\exp \left(-Q^{\prime} t\right)\right)^{2}+Q^{\prime} t \exp \left(-2 Q^{\prime} t\right)
$$

(7) 式は，プローブカー交通量と情報更新周期の二つのパ ラメータのみでエリアカバー率を表現している。よって, 式 を利用するためには，この二つの值をシステム事前検討段階 で入手すればよい。プローブカー交通量は， $Q^{\prime}=\gamma Q=\gamma k v$ で表される。 $\gamma k$ はプローブカーの密度を表し，プローブ カーの投入台数, 及び想定稼働率, 対象道路延長から容易 に事前算出が可能である。 $v$ は走行速度を表し, 走行速度 の值は交通センサスなどから対象地域の統計的な值として 入手可能である。よって，(7) 式は事前計画時に，容易に利 用可能な定式といえる。

\section{3. ケーススタディ}

本章では，前章で導出した理論式 (7) を用いて，プローブ カーの混入率が変化したときに達成可能なエリアカバー率 と情報更新周期との関倸を検討する。エリアカバー率と情 報更新周期は，ともに交通情報サービスの品質を決定する 重要なパラメータであり, 交通情報サービスの種類によって 適切に設定されるべき值である。本章では，プローブカー の台数規模を変化させたときの具体的なエリアカバー率と 情報更新周期の值を示す。

図 3 は, プローブカー交通量を 1 [台/分], 1 [台/5 分], 1 [台/ 時間], 1 [台/日] と変化させたときの情報更新周期とエリア カバー率の関係を示したグラフである。図 3 から，どのプ ローブカー交通量においても，情報更新周期をある程度以 上大きくなるとエリアカバー率は頭打ちになる傾向が見て とれる。よって，目標カバー率を設定する場合には，ある程 度許容範囲を定めて目標值を設定する必要がある。以下で は, エリアカバー率 90\%を目標カバー率と設定して, 各プ ローブカー交通量における実現可能な情報更新周期を示す。

表 1 は, 各プローブ交通量に対応する情報更新周期, プ ローブカーの候補, 及び実現可能な交通情報サービスを示 したものである。表 1 から，プローブカー交通量を 1 [台/ 分]に対しては情報更新周期 2.88 分 (=約 3 分), プロー ブカー交通量 1 [台 $/ 5$ 分] に対しては情報更新周期 14.4 分 （=約 15 分）のリアルタイム交通情報サービスが実現可能 であることを示している。プローブカー交通量に近い車両 をプローブカーの候補として挙げてみると, 情報更新周期 約 3 分の高頻度リアルタイム交通情報サービスを実現する ためには，全カーナビゲーション装着車両に相当する台数 の車両がプローブカーとして必要となる（カーナビ普及率 10-30\% と仮定し，600[台/時]-1200[台/時]の 1 時間交通量 を想定すると，1[台/分]-6[台/分] の交通量に相当）。情報 更新周期約 15 分の低頻度リアルタイム交通情報サービス を実現するためには，テレマティクス機能を搭載した高機 能カーナビゲーション装着車両に相当する台数のプローブ

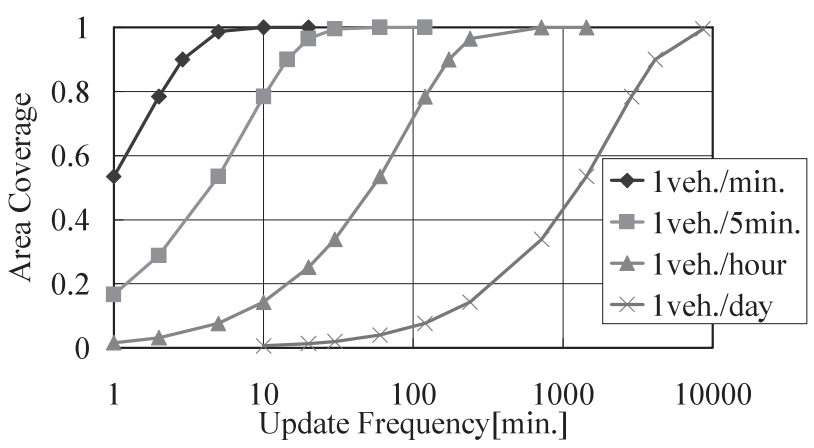

図 3 情報更新周期とエリアカバー率の関係

Fig. 3. Relationship between Area coverage and update frequency. 
表 1 エリアカバー率 $90 \%$ を満足する情報更新周期

Table 1. Update frequency for service available at $90 \%$ area coverage.

\begin{tabular}{|c|c|c|c|}
\hline $\begin{array}{c}\text { Probe volume } \\
\text { (Expected Value) }\end{array}$ & Update frequency & Candidate of probe car & Service available \\
\hline 1veh./min. & $2.88 \mathrm{~min}$ & $\begin{array}{l}\text { Car equipped } \\
\text { car-navigation }\end{array}$ & \multirow{2}{*}{$\begin{array}{l}\text { Real-time } \\
\text { traffic } \\
\text { information }\end{array}$} \\
\hline $1 \mathrm{veh} . / 5 \mathrm{~min}$. & $14.4 \mathrm{~min}$. & $\begin{array}{c}\text { Car equipped } \\
\text { advanced } \\
\text { car-navigation }\end{array}$ & \\
\hline 1veh./hour & $\begin{array}{c}173 \mathrm{~min} . \\
(=\text { about } 3 \text { hours })\end{array}$ & Taxi, Bus & \multirow{2}{*}{$\begin{array}{c}\text { Statistic } \\
\text { traffic } \\
\text { information }\end{array}$} \\
\hline 1veh./day & $\begin{array}{c}4147 \mathrm{~min} . \\
(=\text { about } 3 \text { days })\end{array}$ & $\begin{array}{c}\text { Truck } \\
\text { equipped } \\
\text { on-board unit }\end{array}$ & \\
\hline
\end{tabular}

カー規模で実現できる（カーナビ装着車両のうち $1 / 5$ が高 機能カーナビであると仮定）。一方，プローブカーの交通 量が少ない状態に関しては，プローブカー交通量 1 [台/時 間]に対しては情報更新周期 173 分 (=約 3 時間), プロー ブカー交通量 1 [台/日] に対しては情報更新周期 4147 分 (= 約 3 日）の交通情報サービス，すなわち統計的な交通情報 データを提供するサービスに利用可能なことを示唆してい る。例えば，運行管理用に取り付けた車載機を備えたタク シー，バス，トラックなどをプローブカーとして利用でも 統計的な交通情報サービスは実現できる。

以上の結果から，プローブカーの交通量が少ない段階で もサービスのレベルを変化させることによって，プローブ カーによる交通情報サービスが実現できることを定量的に 示すことができた。

\section{4. 実験による評価}

本章では, 実際のタクシー AVM (Automatic Vehicle Monitoring）システムから取得される GPS の位置情報をプロー ブカーとして活用して，2 章で導出したプローブカー交通 量とエリアカバー率の関係理論式 (7) の有効性を検証した 結果を以下に示す。

実験諸元を表 2 に示す。実験実施にあたっては, 茨城県日 立市（人口約 20 万人の地方都市）を拠点とするタクシー会 社に実験協力を依頼し，タクシーの AVM システムから収集 されるタクシーの位置情報をプローブ情報として利用した。 実験に利用したタクシーの台数は 38 台，実験の対象期間は 2001/07/01 から 2001/07/31 の一ヶ月間とした。実験の対 象としたエリア，及びタクシーの位置情報を地図上にプロッ 卜した結果を図 4 に示す。図 4 左の地図上での点は, 夕ク シーがアップリンクした位置情報を表す。図 4 の位置情報 は，実験期間中最も車両の稼動が多かった 2001/07/06 (金) のうち 19:00-20:00 のデータを表したものである。図 4 か らもわかるように，タクシーの拠点周辺地域にタクシーの 位置情報が分布している。今回の実験では，拠点中心に東
表 2 実験諸元

Table 2. Specification of field tests.

\begin{tabular}{|c|c|}
\hline Location in Experiment & Hitachi City, Ibaraki, JAPAN \\
\hline Area Size & $10 \mathrm{~km} \times 20 \mathrm{~km}$ \\
\hline Term of Experiment & $2001 / 07 / 01-2001 / 07 / 31$ \\
\hline $\begin{array}{c}\text { Number of Probe Cars } \\
\text { (Taxi) }\end{array}$ & 38 \\
\hline Total Link Length & $188.4 \mathrm{~km}$ \\
\hline
\end{tabular}

西約 $10 \mathrm{~km}$, 南北約 $20 \mathrm{~km}$ の位置情報の分布密度が大きい エリアを実験対象エリアとした。図 4 右は, 実験対象エリ アの交通情報作成対象リンクと, プローブ情報から作成し たリンクの速度を表示した地図である。曲線がリンクの速 度出力をした道路を表し, 主要な道路のみを対象としてい る。リンク脇に記載した曲線は，プローブ情報から作成し たリンクの走行速度を表し, リンクの進行方向左側に色分 けで描画している。リンク脇の走行速度が表されている箇 所が，交通情報提供が実現された箇所であり，すなわち工 リアカバー率算出時の提供対象エリアとなる。

関係理論式の検証に際しては，実験期間一ヶ月分のエリ アカバー率の (7) 式から得られる理論值と実験值とを比較 した。(7) 式において理論值を算出するためには，プローブ カー交通量と情報更新周期が必要である。情報更新周期に 関しては，変化させるパラメータとして設定する。プロー ブカー交通量に関しては, 実験データから容易に算出可能 な単位時間内における全走行車両の走行距離を用いて算出 した。走行距離によってプローブカー交通量が算出される 理由を以下に示す。(7) 式におけるプローブカー交通量 $Q^{\prime}$ は, 対象区間での交通状態が一様と仮定すると, 以下の式 で表される。

$$
Q^{\prime}=\gamma Q=\gamma k v
$$

プローブカー走行台数を $n$, 対象区間の道路総延長を $L$ と すると， $\gamma k=n / L$ の関係が成り立つので，これを(8) 式に 代入すると以下の (9) 式となる。 

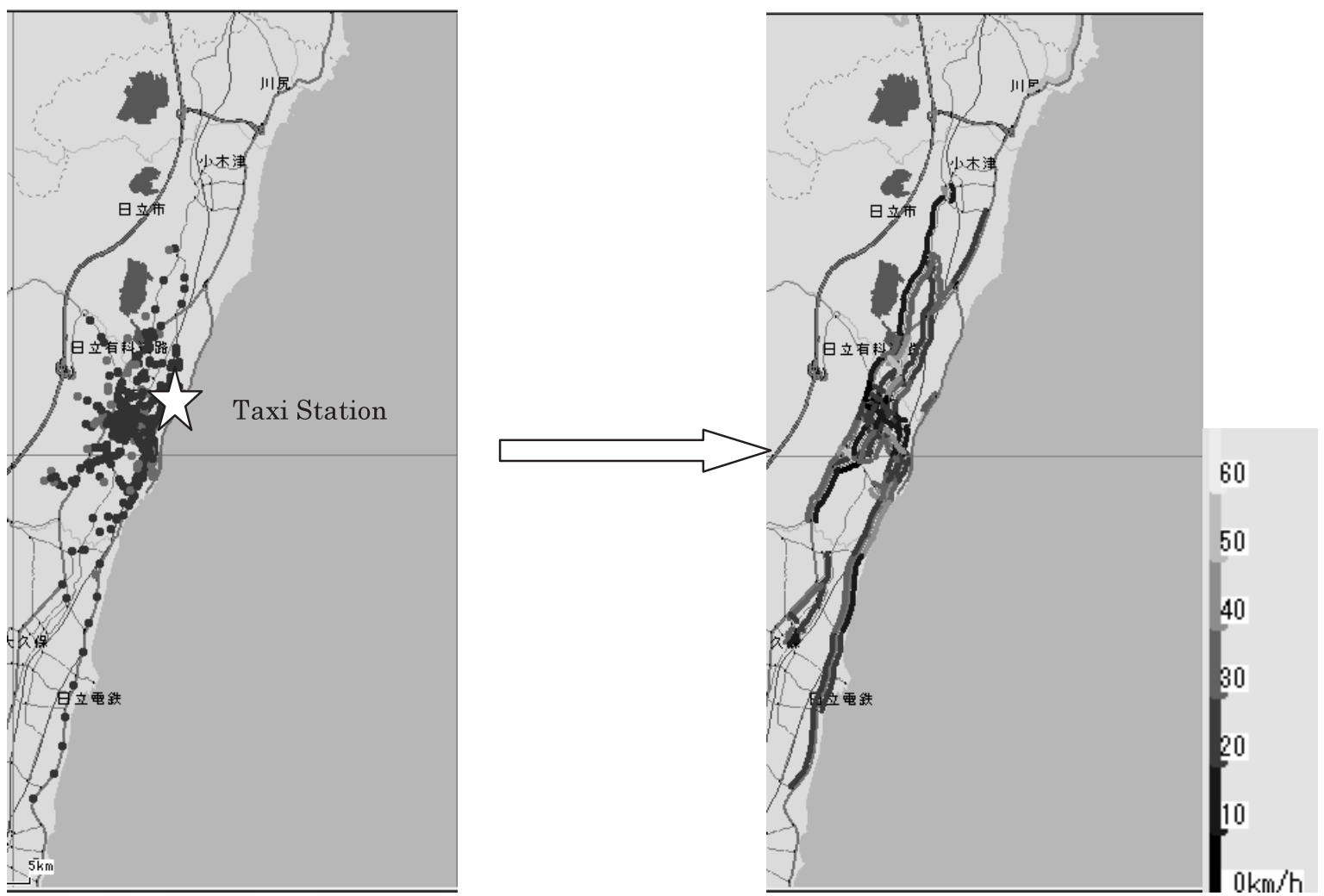

困 4 実験対象エリアと位置情報から交通情報（リンク速度）への変換（2001/07/06 19:00-20:00）

Fig. 4. Map of field test: the probe car data and the average link speed data on 07/06/2001 (19:00-20:00).

$Q^{\prime}=\gamma k v=n v / L$

(9) 式で $v$ はプローブカーの平均速度を表すので, $n v$ はプ ローブカーの速度の合計值と考えることができる。すなわ ち (9) 式の分子は単位時間あたりのプローブカーの走行距 離合計值であり，この值からプローブカー交通量が推定可 能となる。

エリアカバー率の実験值と理論值との比較には，情報更 新周期を変化させて, 時間帯ごとの一ヶ月分のプローブカー 交通量及びエリアカバー率の平均值を算出した。情報更新 周期を 5，10，30，60 分と変化させて，エリアカバー率の実 験值と理論值とを比較した結果をそれぞれ図 5 から図 8 に 示す。図 5 から図 8 の横軸は時間帯, 縦軸はエリアカバー 率を表し，各プロットは情報更新周期 5，10，30，60 分毎 のエリアカバー率の実験值と理論值を表す。また，それぞ れの情報更新周期におけるエリアカバー率の実験值と理論 值の平均誤差率を比較した結果が表 3 である。

図 5 から図 8 と表 3 から，各情報更新周期において実験 から得られたエリアカバー率と理論エリアカバー率とは，良 い一致をしており，理論式の有効性が示された結果となっ ている。また, 一致しているものの, 情報更新周期が大きく なるにしたがって，エリアカバー率の実験值よりも理論值 が大きくなり，互いの差が大きくなっている傾向があるこ とがわかる。情報更新周期が大きくなるにしたがって，誤 差が大きくなった主原因としては以下のことがあげられる。

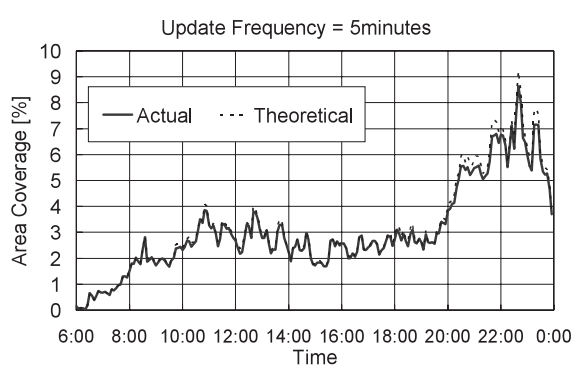

図 5 エリアカバー率の実験值と理論值との比較 (情報更新周期 5 分)

Fig. 5. Actual and theoretical area coverage at 5 minutes update frequency.

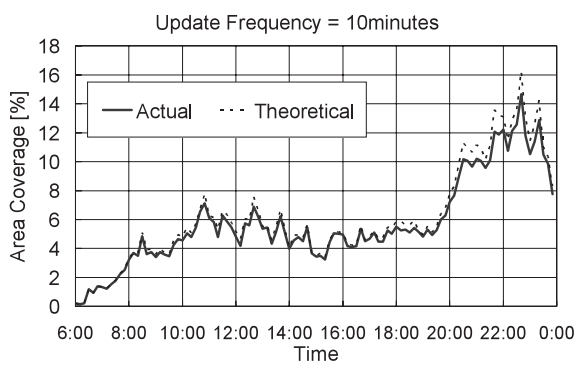

図 6 エリアカバー率の実験值と理論值との比較 （情報更新周期 10 分）

Fig. 6. Actual and theoretical area coverage at 10 minutes update $\mathrm{n}$ frequency. 


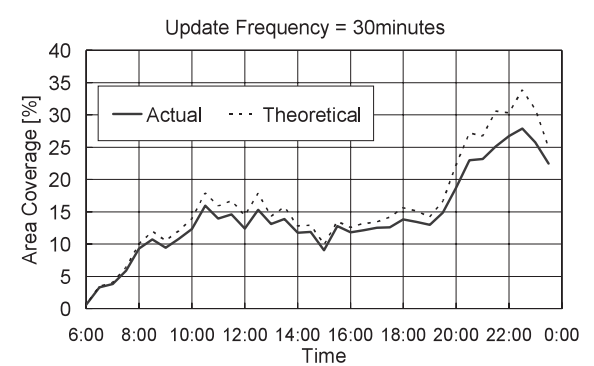

図 7 エリアカバー率の実験值と理論值との比較 (情報更新周期 30 分)

Fig. 7. Actual and theoretical area coverage at 30 minutes update frequency.

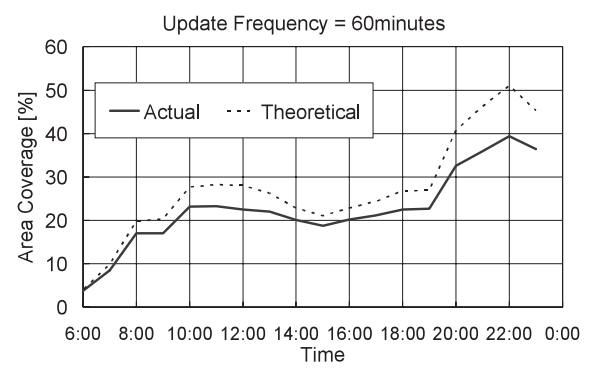

図 8 エリアカバー率の実験值と理論值との比較 (情報更新周期 60 分)

Fig. 8. Actual and theoretical area coverage at 60 minutes update frequency.

表 3 エリアカバー率誤差

Table 3. Error of area coverage.

\begin{tabular}{|c|c|}
\hline Update Frequency & Error Rate \\
\hline $5 \mathrm{~min}$. & $3.8 \%$ \\
\hline $10 \mathrm{~min}$. & $5.8 \%$ \\
\hline $30 \mathrm{~min}$. & $11.5 \%$ \\
\hline $60 \mathrm{~min}$. & $17.9 \%$ \\
\hline
\end{tabular}

情報更新周期が大きくなると，同一情報更新周期内で同一 エリアを走行する車両の比率が増大する。特にタクシーの 場合は，ある拠点を中心として活動する傾向があるので， 情報更新周期を大きくしてもある一定エリア以上の距離を 走行することは考えにくく，その結果実際のエリアカバー 率は頭打ちとなる。一方理論值では, 無限長の直線道路を 走行することを仮定しているので, 情報更新周期を大きく すると，その分だけ走行エリア自体が拡大する。よって情 報更新周期大では理論值 > 実験值の傾向が強まる。逆に, 5 分，あるいは 10 分の情報更新周期の場合は，単位情報更 新周期内での同一車両による同一エリアの繰り返し走行は 考えにくいため，理論值と実験值がよく一致する。本実験 は台数が少ない場合を想定しているが，台数が多い場合で も「単位情報更新周期内での同一車両による同一エリアの 繰り返し走行」の可能性は小さいので, 本論文による理論 式の適用は妥当であると考える。

\section{5. 結 論}

本論文では，プローブカーを有効な交通情報収集手段と して利用するための理論的，実践的な検証を行った。具体 的には，プローブカーの走行頻度と交通情報更新周期との 関係に注目し，プローブカー交通量を指標として，エリア カバー率と交通情報更新周期との関係を定式化した。また, 具体的数值を用いて，交通情報サービスを実現するための 必要なプローブカー混入率を試算した。さらに実際のタク シーAVM システムの位置情報データをプローブカーデー 夕として利用し, 実験によるエリアカバー率を求めて, 本 論文によって導出した関係式の有効性を評価した。

本論文では，一様，一定の交通量を仮定しているが，実 際の交通現象においては情報提供区間の一部で渋滞が発生 し，実際のエリアカバー率が事前算出したエリアカバー率 に到達しない状態も起こりうる。実験結果の考察から, 特 に情報更新周期を大きく設定した状態，具体的には 30 分 以上としたときには，10\%程度エリアカバー率を高く見積 もる可能性があることを考慮し，プローブカー投入台数を 決定する必要がある。

\section{謝 辞}

本研究にあたり，貴重なタクシーの位置情報を提供いた だた（株）茨交日立タクシー様，及び（株）日立国際電 気様には，多大なる謝意を表します。

(平成 17 年 3 月 22 日受付，平成 17 年 9 月 12 日再受付)

$$
\text { 文献 }
$$

(1) K. Yamane, et.al: "Development of VICS with Adaptive Parameter Tuning for Providing Traffic Information", 7th World Congress on Intelligent Transport Systems, Turin, Italy (2000)

(2) T. Fushiki, et.al: "Arrival Time Prediction System Based on Floating Car Data in the Fleet Management ASP", 9th World Congress on Intelligent Transport Systems, Chicago, United States (2000)

(3) M. Kumagai, et.al: "Long-range Traffic Condition Forecast using Feature Space Projection Method", in Proc. of 11th World Congress of ITS Nagoya, (2004) CD-ROM

(4) C.G. Park, et.al: "Determination of Optimal Number of Probe Vehicles for Real-time Traffic Flow Information”, 5th World Congress on Intelligent Transport Systems, Seoul, Korea (1998)

(5) R. Bolla, et.al: "Estimating Road Traffic Parameters from Mobile Communications", 7th World Congress on Intelligent Transport Systems, Turin, Italy (2000)

(6) R. Horiguchi: "Strategic Disposition of Taxi Probe to Accomplish Effective Data Collection for Travel Information Provision - A Theoretical Framework and Its Practice", $1^{\text {st }}$ ITS Symposium, pp.677-683 (2002) (in Japanese)

堀口良太 : 「効率的な交通情報提供サービスのためのタクシープロー ブ配備計画手法の理論と実証」, 第 1 回 ITS シンポジウム 2002 論文 集, pp.677-683 (2002)

( 7 ) T. Fushiki, et.al: "Traffic Condition Prediction by Use of Floating Cars", IPSJ Journal, Vol.43, No.12, pp.3801-3808 (2002-12) (in Japanese) 伏木 匠ほか:「プローブカーを利用した交通情報予測方式の検討」, 情処学論, 43, 12, pp.3801-3808 (2002-12) (2002) 
伏 匠 (非会員) 1973 年 10 月 21 日生。1 998 年 3 月東 京大学大学院工学系研究科産業機械工学専攻修士 課程修了。同年 4 月（株）日立製作所入社，日立 研究所勤務。交通管制システムの開発を経て, 現 在交通情報サービスの研究開発に従事。自動車技 術会, 情報処理学会会員。情報処理学会平成 14 年 ITS 研究会優秀論文賞, 平成 16 年度電機工業 技術功績者奨励賞受賞。

横 田 孝 義 (正員) 1956 年 10 月 28 日生。1 1984 年 3 月東京 工業大学総合理工学研究課精密機械システム専攻 博士後期課程修了。工学博士。同年 4 月（株）日 立製作所入社, 日立研究所勤務。1988 年より 1 年 間米国カーネギーメロン大学客員研究員を経て, 以降，交通管制システム，交通情報サービスの研 究開発に従事。情報処理学会会員。1993 年（社） 交通工学研究会徳岡記念賞受賞。
君田 和 也 (非会員) 1979 年 1 月 24 日生。 2003 年 3 月京都

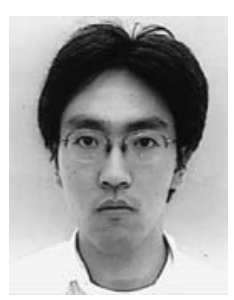
大学大学院情報学研究科知能情報学専攻修士課程 修了。同大学におけるインタラクティブバーチャ ルスタジオの研究を経て, 同年 4 月（株）日立製 作所入社, 日立研究所勤務。現在交通情報際サ一 ビスの研究開発に従事。

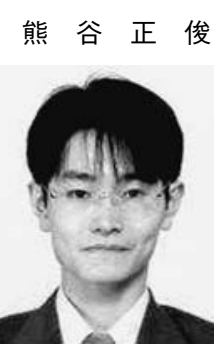

秀論文賞受賞。
(非会員) 1975 年 12 月 2 日生。 2002 年 3 月東 北大学大学院情報科学研究科システム情報科学専 攻博士後期課程修了。博士 (情報科学)。同大学 における脚車輪型移動ロボットの予測歩容制御の 研究を経て, 同年 4 月 (株) 日立製作所入社, 日 立研究所勤務。交通情報サービスの研究開発に従 事。日本機械学会, 日本ロボット学会, 情報処理 学会会員。情報処理学会平成 16 年 ITS 研究会優 